DOI 10.18551/rjoas.2020-07.16

\title{
ECONOMIC AND SCALE EFFICIENCY OF BROILER PRODUCTION IN THE FEDERAL CAPITAL TERRITORY, ABUJA NIGERIA: A DATA ENVELOPMENT ANALYSIS APPROACH
}

Haruna Ezekiel O.*

Department of Agricultural Economics and Extension, Kogi State University, Anyigba, Nigeria

Samuel Elizabeth E.

Department of Agricultural Economics, University of Abuja, Gwagwalada, Nigeria

\author{
Ibinayo Blessing T.
}

Department of Agricultural Economics and Extension, Kogi State University, Anyigba, Nigeria

*E-mail: ezekiel.abu2012@gmail.com

\begin{abstract}
This study examined economic and scale efficiency of broiler production in the Federal Capital Territory, Abuja, Nigeria. Data for the study were collected from 120 broiler farmers through a multistage sampling technique with the aid of structured questionnaire as instrument for data collection. Data were analysed through the use of Data Envelopment Analysis (DEA), Ordinary Least Squares regression analysis and simple descriptive statistics. Result of the analysis revealed that the mean technical efficiency under the CRS and VRS were 0.83 and 0.88 respectively while about $3.33 \%$ and $14.17 \%$ achieved full technical efficiency under the CRS and VRS respectively. The mean allocative, economic and scale efficiency were $0.91,0.76$ and 0.94 respectively while $0.83 \%, 0.83 \%$ and $6.67 \%$ achieved full allocative, economic and scale efficiency respectively. The percentage of farmers that operated under the CRS, IRS and DRS were $6.67 \%, 85.83$ and $7.5 \%$ respectively. We observed that all inputs were used above their cost minimizing quantities with feed being the highest $(44.15 \%)$ followed by labour $(28.98 \%)$ and then Day-old chicks $(14.83 \%)$. The OLS regression results revealed that education and extension contact were negatively related to both technical and economic efficiency while household size and farming experience were positively related to them. We recommend that considerable efforts should be given to the recruitment of extension agents and training of farmers to improve their efficiency.
\end{abstract}

\section{KEY WORDS}

Broiler, efficiency, returns to scale, data envelopment analysis.

Livestock is an important sub-sector in the Nigerian economy. The sub-sector's contribution to the national gross domestic product (GDP) is about 6 to $8 \%$ (ASL2050, 2018). Livestock rearing is an important subsidiary occupation that supplements the income of small holder farm families and rural households in most developing countries. Among livestockbased vocations, poultry production has assumed an important role as a commercial activity with enormous potential for rapid economic growth (Ekunwe et al., 2006). The Nigerian poultry industry is estimated at $\$ 80$ billion ( $\$ 600$ million) and is comprised of approximately 165 million birds, which produced $650,000 \mathrm{MT}$ of eggs and $290,000 \mathrm{MT}$ of poultry meat in 2013(SAHEL, 2015). Poultry production offers the highest turnover rate and the quickest returns to investment outlay in the livestock enterprises. The industry has been described as the fastest means of solving the problem of protein deficiency in Nigeria. For instance, poultry contributes about 15 percent of the total annual protein intake with approximately $1.3 \mathrm{~kg}$ of poultry products consumed per head per annum (Ologbon and Ambali, 2012). Poultry production also improves employment opportunities in Nigeria. An earlier report by 
Mbanasor (2002) showed that about 10 percent of the Nigerian population is engaged in poultry production, mostly in subsistence and small or medium sized farms.

Broiler production is an important enterprise in the poultry subsector in Nigeria. It has incredible potentials for expanding protein supply because of the fast growth rates and productivity of the animal (Omolayo, 2018). Broiler production is carried out in all parts of the country, with no known religious, social or cultural inhibitions associated with their consumption. Specifically, investment in broiler enterprises is attractive because the production cost per unit is low relative to other types of livestock, poultry meat is very tender and commonly used in ceremonies compared to other birds and broiler enterprises have short production circle.

However, broiler production like any other economic venture is dependent on resource inputs. As noted by Etim and Udoh (2007) maximum poultry production depends partly on the environment, technical know-how and the quality of resources employed in the production process. In order to optimize production and ensure sustainability, there is need for judicious management of the resources employed in the broiler enterprise. Inefficiency of resource use and utilization can seriously jeopardize and hamper food production and availability.

There is a dietary protein need or nutritional gap in Nigeria. For instance, the Food and Agricultural Organization (FAO, 2003) recommends that the minimum intake of protein by an average person should be $65 \mathrm{~g}$ per day; of this, $36 \mathrm{~g}$ (i.e. $55.3 \%$ ) should come from animal sources. The animal protein consumption in Nigeria is less than $8 \mathrm{~g}$ per person per day, which is a far cry from the FAO minimum recommendation (Niang and Jubin, 2001). Similarly, chicken supply level falls short of the domestic demand in Nigeria. It has been estimated that about $290,000 \mathrm{MT}$ of poultry meat is produced in 2013 while estimated poultry meat consumption in Nigeria is approximately 1.2 million MT (SAHEL, 2015). Improving the efficiency of broiler farmers is seen as the quickest way of increasing domestic meat supply and bridging the nutritional protein gap in Nigeria.

Previous studies on broiler production dealt majorly on profitability of the industry (see Ibekwe, et al. 2016; Omolayo, 2018; Emokaro and Eweka, 2015; Mamman et al., 2016) while a few others (Ezeh et al., 2012; Emokaro and Emokpae, 2014) examined the technical efficiency of the industry using the stochastic frontier production function. Documented and quantitative empirical studies on economic and scale efficiency in broiler production particularly in FCT that utilized data envelopment analysis (DEA) is scarce. . It is against these study gaps that economic and scale efficiency of broiler production in FCT, Abuja, Nigeria, is carried out. It is hoped that the result of this study would help the farmers understand how efficient their production is and their scale of production. It will bring out the factors affecting their efficiency and ways of improving it.

\section{METHODS OF RESEARCH}

This study was carried out in the Federal Capital Territory (FCT), Abuja. The City is located on Lat. 9.0579 and Long.7.4951. At the 2006 Census, the city of Abuja had a population of 776,298, making it one of the ten most populous cities in Nigeria (NPC, 2006). According to the United Nations, Abuja grew by 139.7\% between 2000 and 2010, making it the fastest growing city in the world. As of 2015 , the city is experiencing an annual growth of at least $35 \%$, retaining its position as the fastest-growing city on the African continent and one of the fastest-growing in the world. As at 2016, the metropolitan area of Abuja is estimated at 6 million persons, placing it behind only Lagos, as the most populous metro area in Nigeria. The territory is currently made up of six area councils, namely; Abaji, Abuja, Bwari, Gwagwalada, Kuje and Kwali Area councils. Agriculture is main part of the economy, with notable farm produce such as Groundnut, Maize, Yam, Sorghum, Cassava and Vegetables.

A multistage sampling technique was used to select respondents for this study. In the first stage, three (3) Area Councils (Abaji, Kuje and Bwari) were purposively selected out of the 6 Area councils in FCT because of their involvement in poultry production. In the second 
stage 2 council wards were randomly selected from each local council giving a total of six (6) council wards. In the third stage 20 poultry farmers were randomly selected from each council wards giving a total of 120 respondents for the study. Structured questionnaire were administered to selected respondents in addition to personal interview for those respondents with low educational background. The data collected was for one production cycle in 2019. Descriptive statistics, ordinary least squares multiples regression and Data Envelopment Analysis were used to analyzed the data.

Data Envelopment Analysis (DEA) was used to estimate economic and scale efficiency of broiler farmers in the study area. DEA developed by Charnes et al. (1978) is a nonparametric, deterministic procedure for evaluating the frontier and employs the best-practice frontier (Bates et.al., 1996). It uses linear programming methods to construct a piecewise frontier of the data. DEA does not require any assumptions about the error term, thus less sensitive to misspecification relative to stochastic frontier approach. However, the deterministic nature of DEA means all deviations from the frontier are attributed to inefficiency.

The technical efficiency (TE) score of a given farmer $n$ is obtained by solving the following input-oriented linear programming (LP) problem:

$$
T E_{n}=\min \theta_{n}
$$

Subject to:

$$
\begin{aligned}
& \sum_{i=1}^{1} \lambda_{i} x_{i j}-\theta_{n} x_{n j} \leq 0 \\
& \sum_{i=1}^{1} \lambda_{i} y_{i k}-y_{n k} \geq 0 \\
& \sum_{i}^{1} \lambda_{i}=1 \\
& \lambda_{i} \geq 0
\end{aligned}
$$

Where: $i=$ one to $I$ farmer; $j=$ one to $\mathrm{J}$ inputs; $k=$ one to $K$ outputs; $x_{i j}=$ the amount of input $j$ used by farmer $i ; ; x_{n j}=$ amount of input $j$ used by farmer $n ; y_{i k}=$ amount of output $k$ produced by farmer $i ; y_{n k}=$ amount of output $\mathrm{k}$ produced by farmer $n ; \lambda_{i}=$ non-negative weights for $I$ firms; $\theta_{n}=$ a scalar $\leq 1$ that defines the TE of farmer $n$. If $\theta_{n}=1$, it means the farmer is technically efficient and if the value is less than one, it means a technically inefficient fir with the level of technical inefficiency equal to $1-T E_{n}$ (Coelli,1995).

The input constraint specified for every input $j$ represented by eq. (2). This constraint requires that the input used by the farmer , weighted by its efficiency must exceed or be equal to a weighted combination of all inputs used by other farmers. The output constraint formulated for every output $k$ is represented by Eq. (3). This equation stipulates that for every output obtained by farmer $n$ must be lower than or equal to the weighted combination of outputs obtained by other farmers. Eq. (4) sets the sum of all weights given to other farmers equal to 1 and ensures that $T E_{n}$ is calculated under the assumption of variable returns to scale (VRS) (Coelli, 1995). Eqs. (1) to (5) is the formulation proposed by Banker et.al. (2008) to calculate pure technical efficiency $\left(T E_{n}=T E_{V R S n}\right)$. If Eq. (4) is omitted, constant returns to scale (CRS) is assumed, and the model reflects the formulation proposed by Charnes et.al. (1978) to calculate the overall technical efficiency $\left(\left(T E_{n}=T E_{C R S n}\right)\right.$.

Economic efficiency (EE) also known as cost efficiency is the ratio of the minimum feasible costs and the actually observed costs for a decision-making unit (Farrell, 1957). A decision-making unit is economically efficient if it is both technically and allocatively efficient. The EE score for a given farmer $n$ is obtained by solving the following input-oriented DEA model to obtain the minimum cost:

$$
M C_{n}=\min \lambda_{i} x_{n j}^{*} \sum_{j=1}^{J} p_{n j} x_{n j}^{*}
$$


Subject to:

$$
\begin{aligned}
& \sum_{i=1}^{j} \lambda_{i} x_{i j}-x_{n j}^{*} \leq 0 \\
& \sum_{i=1}^{I} \lambda_{i} y_{i k}-y_{n k} \geq 0 \\
& \sum_{i=1}^{I} \lambda_{i}=1 \\
& \lambda_{i} \geq 0
\end{aligned}
$$

Where: $M C_{n}=$ the minimum total cost for farmer $n ; p_{n j}=$ the price for input $j$ for farmer $n$ $; x_{n j}^{*}=$ the cost minimizing level of input $j$ for farmer $n$ given its input price and output levels; all other variables are as previously defined. The constraint $\sum_{i=1}^{I} \lambda_{i}=1$ ensures that the total minimum costs for the field are calculated under VRS assumption (Fletschner and Zepeda, 2002; Wu and Prato, 2006).

The economic efficiency for each farmer $n$ can then be estimated using Eq. (11).

$$
E E_{n}=\frac{\sum_{j=1}^{J} P_{n j} x_{n j}^{*}}{\sum_{j=1}^{J} P_{n j} x_{n j}}
$$

Where: The numerator is the minimum total cost obtained for farmer $n$ based on eqs. (6) to (10) and the denominator is the actual total cost observed for farmer $n$. When $E E_{n}=1$, the firm is economically efficient and $E E_{n}<1$ means the firm is economically inefficient.

EE for each firm can also be estimated as a product of technical efficiency and allocative efficiency, expressed as:

$$
E E_{n}=T E_{n} \times A E_{n}
$$

The allocative efficiency (AE) score for farmer $n$ can be estimated given both TE and EE for the farmer as follows:

$$
A E_{n}=\frac{E E_{n}}{T E_{n}}
$$

Where: $E E_{n}=$ economic efficiency calculated for farmer $n$ using Eq. (11) and $T E_{n}=$ technical efficiency calculated for farmer $n$ using Eqs. (1) to (5). When the value of $A E_{n}=1$, the farmer is allocatively efficient and an $A E_{n}<1$ means it is allocatively inefficient.

The scale efficiency $\left(S E_{n}\right)$ for a farmer $n$ is estimated as follows:

$$
S E_{n}=\frac{T E_{C R S_{n}}}{T E_{V R S_{n}}}
$$

Where: $T E_{C R S_{n}}=$ technical efficiency of a farmer $n$ under constant returns to scale and $T E_{V R S_{n}}=$ technical efficiency under variable returns to scale. When $S E_{n}=1$, it means the firm is operating at an optimal scale and when $S E_{n}<1$, the firm is scale inefficient. Scale inefficiency arises as a result of the presence of increasing returns to scale (IRS) or decreasing returns to scale (DRS). The computer program DEAP version 2.1 developed by Coelli (1996) was used to estimate technical, allocative, cost and scale efficiency of broiler farmers.

We used the ordinary least square multiple regression to examine factors affecting technical and economic efficiency of broiler farmers. The use Tobit regression has been criticized for producing inconsistent estimates and contextually inappropriate since the TE scores are fractions and not generated by censoring procedure (Banker and Natarajan, 2008). The OLS regression technique is considered an appropriate method to use in this situation and is believed to produce better results (Banker and Natarajan, 2008). The OLS is 
considered as a stable estimator and its computation is easy (McDonald, 2009). The OLS is expressed as:

$$
Y=\alpha+\beta_{1} X_{1}+\beta_{2} X_{2}+\beta_{3} X_{3}+\beta_{4} X_{4}+\varepsilon
$$

Where: $Y=$ TE or EE scores; $\alpha=$ constant; $\beta_{1} \ldots . . \beta_{4}=$ parameters to be estimated; $X_{1}=$ education (years of formal education) ; $X_{2}=$ household size (number) $; X_{3}=$ farming experience(years) ; $X_{4}=$ extension contact (dummy); $\varepsilon=$ error term.

\section{RESULTS AND DISCUSSION}

Descriptive statistics of some variables used in the DEA analysis are presented in Table 1 while the summary of technical, allocative, economic and scale efficiency indexes of broiler farmers are presented in Table 2. As shown in Table 2, technical efficiency are presented under constant returns to scale $\left(T E_{C R S}\right)$ and variable returns to scale $\left(T E_{V R S}\right)$. The mean $T E_{C R S}$ (overall) is 0.83 with a minimum of 0.39 and a maximum of 1.0 while the mean $T E_{V R S}$ (pure) is 0.88 , a minimum of 0.40 and a maximum of 1.00 . Only about $3.33 \%$ and $14.17 \%$ achieved full technical efficiency $(T E=1)$ under $T E_{C R S}$ and $T E_{V R S}$ respectively. An inefficient farmer can still increase their efficiency by $0.17(17 \%)$ and $0.12(12 \%)$ under $T E_{C R S}$ and $T E_{V R S}$ respectively. Using the stochastic frontier analysis, Omolayo (2018) reported a mean technical efficiency of $74.4 \%$ for broilers farmers while Emokaro and Emokpae (2014) reported that $82.9 \%$ of the respondents had technical efficiency levels of 0.81 and above.

The mean allocative efficiency of broiler farmers is 0.91 with a minimum of 0.38 and a maximum of 1.00 . Only one farmer (about $0.83 \%$ ) achieved full allocative efficiency. From this we can infer that some broiler farmers are not using inputs in a cost-minimizing level given the prices of inputs they face and that on average cost may be reduced by $9 \%$ to attain the level of the best allocative efficient farmer.

Table 1 - Descriptive Statistics of Output, Input and Prices of some Variable Inputs Used in Analysis $(\mathrm{N}=120)$

\begin{tabular}{lllll}
\hline Variables & Mean & Minimum & Maximum & Std. Dev. \\
\hline Broiler Output(kg) & 499.50 & 42.50 & 2490.00 & 508.14 \\
Feed (No/25kg bag) & 45.49 & 4.00 & 200.00 & 47.19 \\
Flock Size (Number) & 236.00 & 20.00 & 1000.00 & 234.73 \\
Labour (Mandays) & 17.35 & 6.00 & 36.00 & 5.60 \\
Cost of feed & 92127.08 & 1000.00 & 343450.00 & 69408.00 \\
Cost of Dayold Chicks & 55635.83 & 3300.00 & 280000.00 & 55940.16 \\
Cost of Labour & 8737.50 & 3000.00 & 18000.00 & 2908.23 \\
\hline
\end{tabular}

Source: Field Survey, 2019.

Table 2 - Summary of Technical, Allocative and Economic Efficiency Indexes of Broiler Farmers

\begin{tabular}{|c|c|c|c|c|c|c|c|c|c|c|}
\hline \multirow{2}{*}{ Class } & \multicolumn{2}{|c|}{ TECRS } & \multicolumn{2}{|c|}{ TEVRS } & \multicolumn{2}{|c|}{ Allo. Eff. } & \multicolumn{2}{|c|}{ Eco. Eff. } & \multicolumn{2}{|c|}{ Scale Eff. } \\
\hline & Freq. & Perc. & Freq. & Perc. & Freq. & Perc. & Freq. & Perc. & Freq. & Perc. \\
\hline 1 & 4 & 3.33 & 17 & 14.17 & 1 & 0.83 & 1 & 0.83 & 8 & 6.67 \\
\hline $0.9-0.999$ & 67 & 55.83 & 68 & 56.67 & 97 & 80.83 & 17 & 14.17 & 88 & 73.33 \\
\hline $0.8-0.899$ & 18 & 15.00 & 8 & 6.67 & 13 & 10.83 & 55 & 45.83 & 14 & 11.67 \\
\hline $0.7-0.799$ & 2 & 1.67 & 3 & 2.50 & 4 & 3.33 & 11 & 9.17 & 4 & 3.33 \\
\hline $0.6-0.699$ & 6 & 5.00 & 17 & 14.17 & 0 & 0.00 & 4 & 3.33 & 2 & 1.67 \\
\hline $0.5-0.599$ & 15 & 12.50 & 5 & 4.17 & 1 & 0.83 & 19 & 15.83 & 4 & 3.33 \\
\hline $0.4-0.499$ & 4 & 3.33 & 2 & 1.67 & 1 & 0.83 & 5 & 4.17 & 0 & 0.00 \\
\hline $0.3-0.399$ & 4 & 3.33 & 0 & 0 & 3 & 2.50 & 8 & 6.67 & 0 & 0.00 \\
\hline Total & 120 & 100 & 120 & 100 & 120 & 100 & 120 & 100 & 120 & 100 \\
\hline Mean & 0.83 & & 0.88 & & 0.91 & & 0.76 & & 0.94 & \\
\hline Median & 0.91 & & 0.94 & & 0.93 & & 0.84 & & 0.98 & \\
\hline Std Dev & 0.17 & & 0.14 & & 0.09 & & 0.18 & & 0.09 & \\
\hline Min & 0.39 & & 0.40 & & 0.38 & & 0.31 & & 0.55 & \\
\hline Max & 1.00 & & 1.00 & & 1.00 & & 1.00 & & 1.00 & \\
\hline
\end{tabular}

Source: Field Survey 2019 and DEAP 2.1. 
The mean economic efficiency of broiler farmers in the study area is 0.76 with a minimum of 0.31 and a maximum of 1.0 . About $0.83 \%$ achieved full economic efficiency. This means that some farmers are economically inefficient and that cost of broiler production can be reduced on average by $24 \%$ to attain the same level of output.

The scale efficiency as shown in Table 1 has a mean of 0.94 with a range of $0.55-1$. About $6.67 \%$ achieved full scale efficiency. The median of 0.98 indicates that most processors operate close to optimal scale size. Thus the TE can be improved by $6 \%$ by adapting the scale of their firms.

Analysis of the returns to scale as presented in Table 3 revealed that about $85.83 \%$ of the farmers operate at increasing returns to scale (sub-optimal scale). This means that most of the farmers sampled are too small and therefore would benefit from an increase in scale. The number of firms operating at constant returns to scale (optimal size) are $8(6.67 \%)$ while $9(7.5 \%)$ operate at decreasing returns to scale (i.e. operating above optimal size).

Table 3 - Returns to Scale Summary Statistics of Broiler Farmers

\begin{tabular}{lll}
\hline Class. of Scale Eff. ${ }^{*}$ & Frequency & Percentage \\
\hline CRS & 8 & 6.67 \\
IRS & 103 & 85.83 \\
DRS & 9 & 7.5 \\
Total & 120 & 100 \\
\hline
\end{tabular}

* CRS: Constant Returns to Scale; IRS: Increasing Returns to Scale.

DRS: Decreasing Returns to Scale.

Source: Computed from DEAP 2.1.

Table 4 shows the distribution of input slacks given the variable returns to scale assumption. Since Slack indicates the excess of an input used, expenditures can be reduced by decreasing the inputs by the amount of slack, without reducing its output (Sivasankari et al. 2017). The mean slack for labour is 4.344 man-day. This means that about $25.04 \%$ of the input is used in excess and this represents the highest slack among all the inputs used in broiler production.

Table 4 - Distribution of Input Slacks for Achieving Optimum (Technically Efficient) Broiler Output

\begin{tabular}{lllll}
\hline \multirow{2}{*}{ Input } & \multirow{2}{*}{ Mean Slack } & $\begin{array}{l}\text { Mean Input } \\
\text { Used }\end{array}$ & $\begin{array}{l}\text { Excess Input Used out of } \\
\text { Mean Input Used (\%) }\end{array}$ & Number of Farmers \\
\hline Feed & 0.027 & 45.49 & 0.06 & 1 \\
Flock Size (Day-old Chick) & 0.088 & 236.00 & 0.04 & 1 \\
Labour & 4.344 & 17.35 & 25.04 & 69 \\
\hline
\end{tabular}

Source: Field Survey, 2019 and DEAP 2.1.

The distribution of excess inputs as well as the optimal input combination that minimizes input costs is presented in Table 5. All the inputs are used above their cost minimizing quantities with feed being the highest (44.15\%) followed by labour $(28.98 \%)$ and then Day-old chicks (14.83\%). Since input prices are taken into consideration in cost minimization, broiler farmers should manage the quantity of feeds and labour used in order to be economically efficient.

Table 5 - Distribution of Excess Input Used for Achieving Minimum (Economically Efficient) Costs of Broiler Production

\begin{tabular}{lllll}
\hline Inputs & $\begin{array}{l}\text { Mean Cost Minimizing } \\
\text { input used }\end{array}$ & Mean Input Used & Excess input Used & $\begin{array}{l}\text { Excess Input Used Out } \\
\text { of Mean Input Used (\%) }\end{array}$ \\
\hline Feed & 25.41 & 45.49 & 20.08 & 44.15 \\
Flock size & 201 & 236.00 & 35.00 & 14.83 \\
Labour & 12.32 & 17.35 & 5.03 & 28.98 \\
\hline
\end{tabular}

Source: Field Survey, 2019 and DEAP 2.1. 
The descriptive statistics of the socio-economic variables used in the OLS regression analysis is presented in Table 6 while Table 7 and Table 8 show the OLS regression estimates of the factors affecting the technical and economic efficiency of broiler farmers respectively. As shown in Table 7 and Table 8, household size and farming experience are positively related to both technical and economic efficiency while education and extension contact are negatively related to both technical and economic efficiency. Education is statistically significant at $5 \%$ in both regressions while farming experience is statistically significant at $5 \%$ in economic efficiency analysis.

Table 6 - Descriptive Statistics of Socioeconomic Variables of Broiler Farmers $(\mathrm{N}=120)$

\begin{tabular}{lllll}
\hline Variable & Unit & Mean & Minimum & Maximum \\
\hline Age & Years & 38 & 18 & 65 \\
Household Size & Number & 5 & 1 & 10 \\
Experience & Year & 5 & 1 & 15 \\
Education & Years of Formal Education & 14 & 6 & 21 \\
\hline
\end{tabular}

Source: Field Survey, 2019.

Table 7 - OLS Estimates of Factors Affecting Technical Efficiency of Broiler Farmers

\begin{tabular}{lllll}
\hline Variable & Coeff. & Std. Error & T-Stat. & Prob. \\
\hline Constant & 0.875 & 0.068 & 12.860 & $0.000^{\star \star *}$ \\
Education & -0.007 & 0.003 & -2.140 & $0.035^{\star *}$ \\
Household Size & 0.004 & 0.008 & 0.500 & 0.618 \\
Farming Experience & 0.009 & 0.007 & 1.320 & 0.190 \\
Extension Contact & -0.003 & 0.041 & -0.070 & 0.945 \\
Model & & & & \\
$\mathrm{R}^{2}$ & 0.055 & & & \\
Adj. $\mathrm{R}^{2}$ & 0.022 & & & \\
$\mathrm{~F}(4,115)$ & 1.670 & & & \\
Prob. $>\mathrm{F}$ & 0.162 & & & \\
No. of Observ. & 120 & & & \\
\hline
\end{tabular}

Source: STATA $12 ;{ }^{* \star *} P<0.01{ }^{* \star} P<0.05$.

Table 8 - OLS Estimates of Factors Affecting Economic Efficiency of Broiler Farmers

\begin{tabular}{lllll}
\hline Variable & Coeff. & Std. Error & T-Stat. & Prob. \\
\hline Constant & 0.755 & 0.070 & 10.790 & $0.000^{\star * *}$ \\
Education & -0.007 & 0.004 & -1.990 & $0.049^{* *}$ \\
Household Size & 0.008 & 0.008 & 0.970 & 0.334 \\
Farming Experience & 0.014 & 0.007 & 2.060 & $0.042^{* *}$ \\
Extension Contact & -0.014 & 0.042 & -0.330 & 0.742 \\
Model & & & & \\
$\mathrm{R}^{2}$ & 0.078 & & & \\
Adj. $\mathrm{R}^{2}$ & 0.046 & & & \\
$\mathrm{~F}(4,115)$ & 2.420 & & & \\
Prob. $>\mathrm{F}$ & 0.052 & & & \\
No. of Observ. & 120 & & & \\
\hline
\end{tabular}

Source: STATA $12 ;{ }^{* \star *} P<0.01{ }^{* *} P<0.05$.

Educational attainment of the farmers facilitates easy training, access to information, understanding and adoption of modern farm practices thereby enhancing their productivity and profitability. According to Ezeh et al., (2012) the level of education attained by a farmer increases his farm productivity and enhances his capacity to understand and evaluate new production technologies. Contrary to result of other studies, the higher the educational attainment of a farmer in the study area, the higher the probability that he/she would be engaged in paid employment and less time would be devoted to farm operations.

Household size is an important source of family labour. Given the labour intensive nature of broilers production, availability of labour is critical for its success. Depending on the family's composition, the findings suggest that broiler farmers could draw some level of family labour from their household members thereby reducing the cost of hired labour. This 
supports most of the studies that confirmed large house size among the farming households where they see family size as a work force that supply the most needed labour requirement for production activities (Emaikwu et al., 2011).

It is generally expected that productivity increases with years of experienced (Umar, 2013). The longer the years of farming experience, the more the knowledge acquired, the more efficient the farmer is expected to be. Farmers master the techniques of production and avoid previous mistakes. Experienced broiler farmers are likely to make better decisions to enhance productivity and income.

Contact with extension agents is expected to facilitate training, information dissemination and adoption of improved or modern farming techniques. What this result suggests is that broiler farmers in the study area are not having the required contact with extension agents.

\section{CONCLUSION}

This study used DEA and OLS regression to estimate technical, allocative and economic efficiency of broiler farmers and the factors affecting technical and economic efficiency in FCT, Abuja-Nigeria. Results of the analysis revealed that:

- The mean technical efficiency under the CRS and VRS are 0.83 and 0.88 respectively. About $3.33 \%$ and $14.17 \%$ achieved full technical efficiency under the CRS and VRS respectively. This means that most of the farmers are inefficient and revealed a considerable room for improvement;

- The mean allocative, economic and scale efficiency are 0.91, 0.76 and 0.94 respectively while $0.83 \%, 0.83 \%$ and $6.67 \%$ achieved full allocative , economic and scale efficiency respectively. This also implies that considerable number of farmers are allocatively, economically and scale inefficient;

- The percentage of farmers that operate under the CRS, IRS and DRS are $6.67 \%$, 85.83 and $7.5 \%$ respectively. This means that most farmers are too small (suboptimal) and would benefit from an increase in size;

- All inputs are used above their cost minimizing quantities with feed being the highest (44.15\%) followed by labour (28.98\%) and then Day-old chicks (14.83\%). Broiler farmers should manage the quantity of feeds and labour used in order to be economically efficient;

- OLS regression results revealed that education and extension contact are negatively related to both technical and economic efficiency while household size and farming experience are positively related to them. It is recommended that considerable efforts should be given to the recruitment of extension agents and training of farmers to improve their efficiency.

\section{REFERENCES}

1. ASL 2050 (2018). Livestock production systems spotlight Nigeria. FOA, Rome Italy.

2. Banker, R.D., Charnes, A. and Cooper, W.W. (1984). Some Models for Estimating Technical and Scale Inefficiencies in Data Envelopment Analysis. Management Science. 30:1078-92.

3. Banker, R.D. and Natarajan, R. (2008). Evaluating Contextual Variables Affecting Productivity Using Data Envelopment Analysis. Operational Resources. 56 (1): 48-58.

4. Bates, J.M., Baines, D. and Whynes, D.K. (1996). Measuring the Efficiency of Prescribing by General Analysis. Journal of Operational Research Society. 47 (12): $1443-51$.

5. Charnes, A., Cooper, W.W. and Rhodes, E. (1978). Measuring the Efficiency of Decision Making Units. European Journal of Operational Research 2:429-44.

6. Coelli, T.J. (1995). Recent Developments in Frontier Modelling and Efficiency Measurement. Australian Journal of Agricultural and Resource Economics. 39 (3): 219-45 
7. Coelli, T.J. (1996). A Guide to DEAP version 2.1: A Data Envelopment Analysis (computer) Program. Armidale, Australia: Centre for Efficiency and Productivity Analysis, University of New England.

8. Emaikwu, K.K. (2011). Determinants of Flock Size in Broiler Production in Kaduna State of Nigeria. Journal of Agricultural Extension and Rural Development .3(11): $202-211$.

9. Emokaro, C. O. (2014). Technical Efficiency and Production Elasticity of Broiler Production in Edo State, Nigeria. Applied Tropical Agriculture. 19(1):59-65.

10. Emokaro, C. O. (2015). A Comparative Analysis of Profitability of Broiler Production Systems in Urban Areas of Edo State, Nigeria. J. Appl. Sci. Environ. Manage. 19 (4): 627 -631 .

11. Etim, N. A. and Udoh, E. J. (2007). Measuring Technical Efficiency of Broiler Production among Rural Farmers in Akwa Ibom State. Proceeding of the Technical Annual Conference of the Nigeria Society of Animal Production held at the University of Calabar, Calabar. Cross River State, March 18-21:412 -414.

12. Ezeh C.I., Anyiro C.O. and Chukwu J. A. (2012). Technical Efficiency in Poultry Broiler Production in Umuahia Capital Territory of Abia State, Nigeria. Greener Journal of Agricultural Sciences. 2 (1): 001-007.

13. Farrell, M.J. (1957). The Measurement of Productive Efficiency. Journal of the Royal Statistical Society. Series A (General).120 (3): 253-90.

14. Fletschner, D.K. and Zepeda, L. (2002). Efficiency of Small Landholders in Eastern Paraguay. Journal of Agricultural and Resource Economics.27:554 - 72.

15. Food and Agriculture Organizations (2003). Food Security Concepts and Measurements. In Trade Reforms and Food Security: Conceptualizing the Linkages. Experts Consultative Forum held in Rome, Italy July 11 - 12.

16. Ibekwe U.C., Chikezie, C., Ibeagwa, O.B., Onyeoziri, M.N (2014). Broilers Production among Small Scale Producers in Imo State, Nigeria: A Profit Function Analysis. International Journal of Research in Agriculture and Forestry. 2 (1): 40 - 45.

17. Mamman, B. D., Anzaku, T.A.K. and Umar, H.S. (2016). Profitability Evaluation of Broiler Production among Small-Scale Commercial Poultry Farmers in Nassarawa - Eggon Local Government Area of Nasarawa, State, Nigeria. International Journal of Agriculture and Earth Science .2 (1):52-57.

18. Mbanasor, J. A. (2002). A Resource Use Pattern among Poultry Enterprises in Abia State Nigeria. Nigeria journal of Animal Production. 29: 64-70.

19. McDonald, J. (2009). Using Least Squares and Tobit in Second Stage DEA Efficiency Analyses. European Journal of Operational Resource.197: 792-98.

20. Niang, T. and Jubrin, S. (2001). Quarterly Newsletter of the Nigeria Agriculture. Question and Answer Service 1(3).

21. NPC (National Population Commission). Population Census of the Federal Republic of Nigeria; Draft Report. 2006.

22. Ologbon, A. C. and Ambali, I. (2012). Poultry Enterprise Combination among Small Scale Farmers in Ogun state, Nigeria. A technical efficiency approach. Journal of Agriculture and Veterinary Science Pp8

23. Omolayo, J .O. (2018). Economic Analysis of Broiler Production in Lagos State Poultry Estate, Nigeria. Journal of Investment and Management .7(1): 35 - 44.

24. SAHEL (2015). An Assessment of the Nigerian Poultry Sector. http://sahelcp.com/anassessment-of-the-nigerian-poultry-sector/.SAHEL 11: 1-3.

25. Sivasankari, B., Vasaanthi, R. and Prema, P. (2017). Determination of Technical Efficiency in Paddy Farms of Canal Irrigated Systems in Tamil Nadu: A Data Envelopment Analysis Approach. International Journal of Chemical Studies. 5(5): 33-36.

26. Umar, M. (2013). Economic Analysis of Poultry-Egg Production in Bauchi Local Government Area, Bauchi State, Nigeria. Unpublished M.Sc. Dissertation Thesis, Department of Agricultural Economics and Rural Sociology, Faculty of Agriculture, Ahmadu Bello University, Zaria, Nigeria.

27. Wu, S. and Prato, T. (2006). Cost efficiency and scope economies of crop and livestock farms in Missouri. Journal of Agricultural and Applied Economics. 38:539-53. 